J. Akademika Kim. 7(1): 23-27, February 2018

ISSN 2302-6030 (p), 2477-5185 (e)

\title{
PENERAPAN MODEL PEMBELAJARAN KOOPERATIF TIPE MAKE A MATCH UNTUK MENINGKATKAN HASIL BELAJAR SISWA PADA MATERI LARUTAN ELEKTROLIT DAN NON ELEKROLIT DI KELAS X MADRASAH ALIYA DDI LONJA
}

The Application Cooperative Learning type Make A Match to Improve stundent's Achievement in Electrolyte and Non-Electrolyte Solutions Material in Class X Madrasah Aliyah DDI Lonja

\author{
* Muslimah, Kasmudin Mustapa dan Ratman \\ Pendidikan Kimia/FKIP - Universitas Tadulako, Palu - Indonesia 94118 \\ Received 11 December 2017, Revised 10 January 2018, Accepted 12 February 2018
}

\begin{abstract}
This research describes the differences of student's learning with the application of cooperative learning type make a match in the electrolyte and non-elekctrolyte at the X grade student's of the Madrasah Aliya DDI Lonja. This research used quasi experimental with non randomized pretest-posttest control group design. This research was conducted with two groups: $X A$ as the experimental $(n=21) X B$ as the control group $(n=18)$. The data findings means score of experimental group $\left(\mathrm{X}_{1}\right)$ is 70,5 with the standar deviation 9,6 and the control group ( $\left.\mathrm{X}_{2}\right)$ is 62.0 with the standard deviation is 6 . Based on the results, the researcher concludes cooperative learning type make a match has better than control class that used conventional learning model.
\end{abstract}

Keywords: Cooperative, make a match, electrolyte, non-electrolyte solutions, learning outcomes.

\section{Pendahuluan}

Pendidikan mempunyai peran yang sangat strategis dalam meningkatkan kualitas sumber daya manusia dan upaya mewujudkan cita-cita bangsa Indonesia dalam mewujudkan kesejahteraan umum dan mencerdaskan kehidupan bangsa. Pemerintah merumuskan dalam Undang-Undang Republik Indonesia No 20 tahun 2003 Pasal 1 tentang Sistem Pendidikan Nasional yang menjelaskan bahwa "Pendidikan adalah usaha sadar dan terencana untuk mewujudkan suasana belajar dan proses pembelajaran agar peserta didik secara aktif mengembangkan potensi dirinya untuk memiliki kekuatan spiritual keagamaan, pengendalian diri, kepribadian, kecerdasan, akhlak mulia, serta ketrampilan yang diperlukan dirinya, masyarakat, bangsa, dan negara" (Astika \& Nyoman, 2011).

Keberhasilan suatu proses pembelajaran salah satunya ditentukan oleh peran guru dalam mengembangkan metode yang digunakan. Peran guru dalam hal ini adalah bagaimana kreatifitas guru dalam mendesain proses belajar mengajar yang efektif, yaitu proses belajar yang mengembangkan metode dengan penekanan pada partisipasi dan keaktifan siswa di kelas. Penggunaan pola pembelajaran berpusat pada siswa tentunya diharapkan untuk mewujudkan kondisi yang konduktif sehingga mendorong siswa untuk termotivasi melakukan kegiatan belajar secara aktif. Kenyataan di lapangan menunjukkan bahwa tercapainya proses belajar mengajar yang efisien,

*Correspondence

Muslimah

Program Studi Pendidikan Kimia, Fakultas Keguruan dan

Ilmu Pendidikan, Universitas Tadulako

e-mail: muslimahmuche43@gmail.com

Published by Universitas Tadulako 2018 bukan karena hanya dengan metode yang bersifat berpusat pada guru atau komunikasi satu arah, akan tetapi harus juga dengan metode pembelajaran yang bersifat multi arah atau pembelajaran berpusat pada siswa. Apabila hal ini tidak bersinergi, maka akan mempengaruhi kualitas pendidikan menjadi rendah. Dalam kurikulum 2013 kegiatan proses belajar berpusat pada siswa sehingga memerlukan penggunaan pendekatan pengajaran strategi, metode dan tehnik sesuai dengan pendekatan untuk melibatkan partisipasi siswa aktif dalam proses belajar (Durukun, 2011).

Siswa lebih banyak diam pada saat pembelajaran berlangsung dan juga siswa kurang memperhatikan, hal ini dikarnakan pembelajaran yang terjadi hanya berlaku satu arah. Keadaan kelas serta metode belajar mengajar harus dibuat lebih menyenangkan sehingga siswa bisa berinteraksi satu sama lain, diperlukan model dan metode pembelajaran yang lebih inovafatif sehingga dapat membuat siswa lebih aktif dan bersemangat. Suyono \& Haryanto (2012), mengemukakan bahwa pada awal pertengahan kedua abad ke-20 model pembelajaran kooperatif sudah berkembang menuju berpusat kepada siswa. Menurut Tran (2014), pembelajaran kooperatif secara umum terdiri dari metode pembelajaran dimana guru mengatur siswa ke dalam kelompok-kelompok kecil, yang kemudian bekerja sama untuk saling membantu mencapai tujuan pembelajaran bersama. Model pembelajaran kooperatif dapat meningkatkan hasil belajar siswa karena siswa akan memiliki lebih banyak kesempatan untuk saling membantu, pertukaran sumber daya yang dibutuhkan, komunikasi yang efektif, dan saling pengaruh. Pembelajaran kelompok tidak hanya membantu siswa dalam berinteraksi satu sama lain, namun secara tidak langsung dapat menumbuhkan 
ide-ide alternatif, serta menghasilkan suatu pemecahan masalah melalui adanya diskusi (Pandey \& Kishore, 2003). Tugas guru bukan lagi aktif mentransfer pengetahuan (transfer of knowledge) dari benaknya ke benak siswa di dalam kelas, tetapi menciptakan kondisi belajar yang merencanakan jalanya pembelajaran dengan pilihan materi yang cocok dan representatif, sehingga mereka mendapat pengalaman belajar yang optimal (Jumariadi, 2012).

Model pembelajaran kooperatif tipe make a match atau mencari pasangan dilakukan dengan memberikan kesempatan kepada siswa untuk mencari pasangan kartu soal dan kartu jawaban. Make a match merupakan metode pembelajaran dimana setiap siswa memegang satu kartu soal atau jawaban dan siswa dituntut untuk bekerja sama dengan siswa lain dalam menemukan kartu jawaban maupun kartu soal yang dipegang pasangannya dengan batas waktu tertentu (Karina, dkk., 2012).

Penelitian yang dilakukan Manik (2012), menunjukan bahwa ada pengaruh penerapan model pembelajaran Make a Match terhadap hasil belajar siswa pada pokok bahasan Hidrokarbon yang menggunakan handout. Hal ini menunjukkan penggunaan handout memberikan pengaruh yang baik terhadap hasil belajar siswa. Sehingga dapat disimpulkan bahwa model pembelajaran make a match menggunakan handout berpengaruh dalam peningkatan hasil belajar siswa di SMA pada pokok bahasan hidrokarbon.

Artikel ini mendeskripsikan adanya peningkatakan hasil belajar siswa dengan penerapan model pembelajaran kooperatif tipe make a match pada materi larutan elektrolit dan non-elektrolit di kelas X Madrasah Aliya DDI Lonja.

\section{Metode}

Penelitian ini dilakasanakan di Madrasah Aliya DDI Lonja. Populasi dalam penelitian ini adalah semua siswa kelas X di Madrasah Aliya DDI Lonja yang terdaftar pada tahun ajaran 2015-2016 sebanyak 39 siswa. Sampel dari penelitian ini adalah 21 siswa kelas XA dan siswa kelas XB. Hasil belajar siswa kelas XA dan XB relatif sama namun tingkat ketuntasan siswa kelas $\mathrm{XB}$ lebih baik dibanding siswa kelas XA. Sehingga hal tersebut menjadikan XA ditetapkan sebagai kelas eksperimen dan kelas XB sebagai kelas kontrol. Teknik penentuan sampel dilakukan secara sampling jenuh teknik penentuan sampling jenuh dilakukan apabila semua populasi digunakan sebagai sampel (Sugiyono, 2010).

\section{Tehnik pengumpulan data}

Teknik pengumpulan data pada penelitian ini diperoleh melalui proses belajar mengajar dan tes hasil belajar tentang larutan elektrolit dan nonelektrolit yang diberikan kepada siswa sebelum dan setelah pembelajaran berlangsung. Penelitian ini dilaksanakan dalam tiga tahap yaitu tahap persiapan, tahap pelaksanaan, dan tahap akhir. Adapun tahap-tahap tersebut adalah sebagai berikut:

\section{Tahap persiapan}

Dalam tahap persiapan ini yang dilakukan adalah, observasi lokasi penelitian di Madrasah Aliya DDI Lonja, menentukan populasi dan sampel penelitian. Membuat RPP (rencana pelaksanaan pembelajaran) dengan model pembelajaran kooperatif tipe make a match meliputi pembuatan materi ajar atau bahan ajar dengan menulis pokok-pokok materi pada potongan kertas (kartu), membuat tes awal (pretest), menyusun tes hasil belajar untuk mengukur penguasaan materi pelajaran, melakukan tes pada kelas XI IPA di Madrasah Aliya DDI Lonja.

\section{Tahap pelaksanaan}

Pemberian evaluasi pada awal pembelajaran test awal (pretest) pada pertemuan pertama untuk memperoleh data awal hasil belajar siswa pada kelas eksperimen dan kelas kontrol dengan menggunakan test pilihan ganda yang telah disusun sebelumnya, melakukan kegiatan belajar mengajar untuk materi larutan elektrolit dan nonelektrolit dengan menggunakan model pembelajaran kooperatif tipe make a match pada kelas eksperimen dan melakukan kegiatan belajar mengajar pada kelas kontrol tanpa menggunakan model pembelajaran kooperatif make a match tetapi dengan model pembelajaran konvensional, pemberian tes hasil belajar pada pertemuan terakhir pada kelas eksperimen dan kelas kontrol untuk memperoleh data hasil belajar siswa (posttest).

\section{Tahap akhir}

Kegiatan yang dilakukan pada tahap ini adalah pengolahan dan analisis data serta pelaporan hasil penelitian.

\section{Instrumen penelitian}

Penelitian ini menggunakan instrumen berupa lembar kerja siswa, yang merupakan lembaranlembaran yang berisi tugas yang harus dikerjakan oleh siswa. Lembar kerja siswa berisikan petunjuk, tugas, dan latihan yang terkait dengan materi yang dipelajari sehingga siswa akan mampu mengingat suatu konsep lebih lama karena konsep tersebut diperoleh melalui keterlibatan mental atau berpikir yang tinggi. Tes hasil belajar bertujuan untuk mendapatkan data kecakapan individu sebagai hasil proses belajar siswa pada meteri larutan elektrolit dan non-elektrolit dengan menggunakan model pembelajaran kooperatif tipe make a match dan model pembelajaran konvensional. Tes hasil belajar dalam bentuk pilihan ganda berjumlah 21 butir soal, dengan tiap butir soal terdapat 5 item pilihan jawaban. Syarat-syarat tes yang baik harus memilik validitas, reabilitas tingkat kesukaran, dan daya pembeda. 


\section{Tehnik analisa data}

Data hasil penelitian dianalisis dengan metode analisis statistik deskriptif dan statistik inferensial. Statistik deskriptif adalah statistik yang berfungsi untuk mendeskripsikan atau memberi gambaran terhadap objek yang diteliti melalui dua sampel atau populasi sebagaimana adanya (Sugiyono, 2010). Gambaran tentang pencapaian masingmasing variabel adalah dengan menentukan hubungan nilai pretest dan posttest pada kelas eksperimen maupun kelas kontrol dengan menggunakan uji $N$-gain (Alep, dkk, 2015).

\section{Hasil dan Pembahasan}

Data hasil belajar diperoleh dari 39 siswa yang terdiri dari 21 siswa Kelas XA dan 18 siswa Kelas XB. Posttest yang dilakukan bertujuan untuk mengetahui sejauh mana peningkatan hasil belajar siswa dengan model pembelajaran kooperatif tipe make a match pada materi larutan eleketrolit dan non-elektrolit di kelas X Madrasah Aliya DDI Lonja. Hasil perhitungan nilai rata-rata dan nilai standar deviasi tes akhir hasil belajar kimia pada materi larutan elektrolit dan non-elektrolit pada kelas ekperimen dan kelas kontrol, seperti pada Tabel 1.

Tabel 1. Analisis hasil belajar kelas experimen dan kelas kontrol

\begin{tabular}{ccc}
\hline \multirow{2}{*}{ Uraian } & \multicolumn{2}{c}{ Tes Akhir (Posttest) } \\
\cline { 2 - 3 } & $\begin{array}{c}\text { Kelas } \\
\text { eksperimen }\end{array}$ & $\begin{array}{c}\text { Kelas } \\
\text { kontrol }\end{array}$ \\
\hline Sampel & 21 & 18 \\
Nilai terendah & 43 & 52 \\
Nilai tertinggi & 86 & 76 \\
Skor rata-rata & 70,5 & 62,0 \\
Standar & 9,6 & 6 \\
deviasi & & \\
\hline
\end{tabular}

Berdasarkan Tabel 1 dapat dilihat bahwa skor rata-rata pada kelas eksperimen lebih tinggi dibandingkan pada kelas kontrol, hasil posttest yaitu nilai terendah 43 pada kelas eksperimen, pada kelas kontrol 52, untuk nilai tertinggi pada kelas eksperimen 86 dan kelas kontrol 76 sedangkan untuk skor rata-rata nilai posttest pada kelas eksperimen 70,5 dengan standar deviasi 9,6 dan kelas kontrol 62,0 dengan standar deviasi 6, hal ini menunjukan bahwa hasil belajar yang diperoleh pada kelas eksperimen lebih baik dibanding pada kelas kontrol sehingga hal tersebut membuktikan bahwa ada peningkatan hasil belajar siswa dengan penerapan model pembelajaran kooperatif tipe make a match. Hal ini juga dibuktikan oleh Maula \& Rustopo (2012), dimana diperoleh nilai rata-rata kelas eksperimen 86,25 dan kelas kontrol 66,00, menyimpulkan bahwa model pembelajaran kooperatif tipe make a match mempengaruhi hasil belajar dibandingkan metode konvensional.
Hasil pengujian $N$-Gain bertujuan untuk menggambarkan data yang telah terkumpul berdasarkan pencapaian hasil belajar siswa sebelum (pretest) dan sesudah (posttest) baik pada kelas eksperimen maupun pada kelas kontrol. Hasil pengujian $N$-Gain diperoleh data jumlah siswa dengan kriteria $N$-Gain rendah, sedang, dan tinggi seperti yang dapat dilihat pada Gambar 1 .

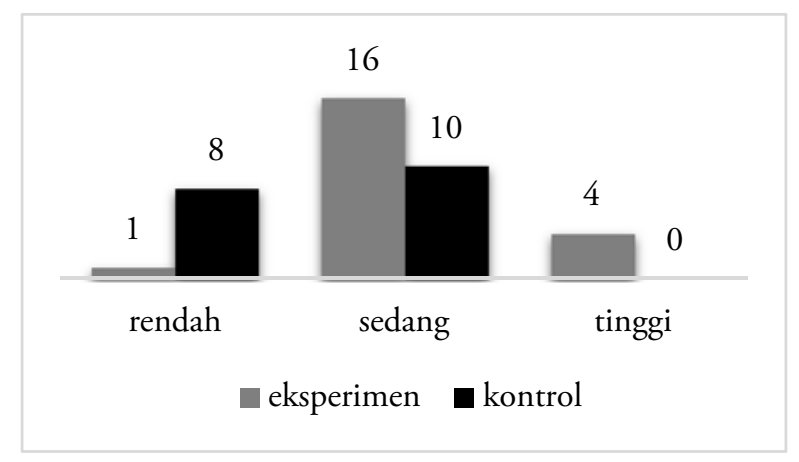

Gambar 1. N-Gain Siswa di kelas eksperimen dan kelas kontrol

Berdasarkan Gambar 1 diatas menunjukan bahwa ada perbedaan peningkatan hasil belajar antara kelas eksperimen dan kelas kontrol, dimana dapat dilihat pada kelas eksperimen kriteria nilai terendah 1 orang pada kelas kontrol 8 orang, untuk kriteria sedang kelas eksperimen 16 orang, kelas kontrol 10 orang, dan untuk kriteria tinggi pada kelas eksperimen 4 orang dan kelas kontrol tidak ada. Hasil ini menunjukan bahwa model pembelajaran kooperatif tipe make a match memberikan hasil belajar yang lebih baik dibandingkan pada siswa yang menggunakan model pembelajaran konvensional.

Model pembelajaran kooperatif tipe make a match pada materi larutan elektrolit dan nonelektrolit memberikan hasil belajar yang lebih tinggi dibandingkan dengan model pembelajaran konvensional hal ini dikarnakan model pembelajaran kooperatif tipe make a match memiliki kelebihan yaitu membuat siswa untuk bisa berpartisipasi satu sama lain dengan teman sekelasnya sehingga membuat pembelajaran lebih menyenangkan, selain itu pula materi pembelajaran yang disampaikan akan lebih menarik perhatian siswa, hal ini juga dibuktikan oleh Astika \& Nyoman (2011), dalam penelitianya yang menyimpulkan bahwa model pembelajaran kooperatif tipe make a match lebih efektif meningkatkan hasil belajar siswa bila dibandingkan dengan model pembelajaran konvensional. Pada umumnya siswa mendapat penuturan secara lisan dan bersifat pasif, yakni menerima apa yang dijelaskan oleh guru tanpa berbuat semaksimal mungkin (Sutarno, 2010). Dengan model pembelajaran make a match, peserta didik dapat bekerjasama dengan anggota kelompoknya serta dapat berkompetisi dengan kelompok lain (Sulistyaningsih dkk., 2014). Setiap proses belajar 
mengajar keberhasilanya diukur dari seberapa jauh hasil belajar yang dicapai siswa (Lestari, 2012).

Namun demikian ada beberapa hal yang menjadi kendala-kendala dalam penerapan model pembelajaran kooperatif tipe make a match ini yakni guru dituntut untuk dapat menguasai kelas serta mampu mengontrol kegaduhan siswa pada proses belajar terutama pada saat kelompok pemagang kartu soal dan jawaban saling mencari pasangannya yang menyebabkan kegaduhan dalam kelas, namun demikian peneliti berinisiatif untuk mengurangi kegaduhan dalam kelas dengan cara mengatur posisi kelompok-kelompok tersebut berbentuk huruf $U$, dan mengupayakan kelompok pemegang kartu soal dan kartu jawaban berjajar saling berhadapan, kemudian memerintahkan siswa mencari pasanganya yang sejajar dihadapan mereka terlebih dahulu, sehingga keefektifan kelompok menjadi lebih baik serta dapat mengurangi kegaduhan. Metode make a match juga memerlukan pembatasan waktu yang baik agar siswa tidak bermain-main selama pembelajaran berlangsung namun hal ini dapat dikurangi dengan memberikan pemahaman awal kepada siswa serta kontrol yang ketat di dalam penggunaan metode make a match.

Dari uraian di atas dapat disimpulkan bahwa penelitian eksperimen dengan menggunakan model pembelajaran kooperatif tipe make a match dapat memberikan dampak yang lebih baik terhadap hasl belajar siswa pada kelas X Madrasah Aliya DDI Lonja. Meskipun demikan ada hal-hal yang perlu dikembangkan melalui penelitian yang lebih lanjut tentang model pembelajaran kooperatif tipe make a match terhadap hasil belajar siswa dan dampaknya terhadap pembelajaran.

\section{Kesimpulan}

Berdasarkan hasil yang diperoleh, dapat disimpulkan bahwa penerapan model pembelajaran kooperatif tipe make a match menunjukkan ada perbedaan peningkatan hasil belajar pada kelas eksperimen dibandingkan pada kelas kontrol. Hasil belajar yang diperoleh setelah penerapan model pembelajaran kooperatif tipe make a match pada kelas eksperimen diperoleh skor rata-rata 70,5 sedangkan pada kelas kontrol dengan model pembelajaran konvensional skor rata-rata yang diperoleh 60,2. Hal ini memperlihatkan bahwa model pembelajaran kooperatif tipe make a match memiliki hasil yang lebih baik dibandingkan pada kelas kontrol yang menggunakan model pembelajaran konvensional.

\section{Ucapan Terima Kasih}

Penulis mengucapkan terima kasih kepada Agustina Kepala Sekolah Madrasah Aliya DDI Lonja, Mutmainnah dan Arini selaku guru kimia di MA DDI Lonja, seluruh siswa kelas X MA DDI Lonja, dan seluruh pihak yang telah membantu penulis dalam menyelesaikan penelitian ini.

\section{Referensi}

Alep, B., Walanda, D. K., \& Hamzah, B. (2015). Penerapan metode pembelajaran SQ3R berbantuan internet terhadap hasil belajar siswa kelas $\mathrm{X}$ pada materi sistem periodik unsur di SMA labschool palu. Jurnal Akademika Kimia, 4(1), 44-49.

Astika, N. \& Nyoman, N. A. (2011). Efektivitas model pembelajaran kooperatif tipe make a match terhadap hasil belajar. Jurnal Pendidikan Program Studi Pendidikan Fisika IKIP PGRI Semarang, 28(110), 110-117.

Durukun, E. (2011). Effect of cooperative integrated reading an composition (CIRC) technique on reading-writing skills educational research and reviews. Academic Journals, 6(1), 102-109.

Jumariadi, B. (2012). Pengembangan perangkat pembelajaran matematika model kooperatif tipe to stay to stray dengan pendekatan konstruktifisme untuk meningkatkan kemampuan komunikasi matematis siswa. Journal of Primary Educational, 1(1), 1-20.

Karina, I., Warastiti, N. H., Marlina, R., Suyanto, I. \& Suryandari, K. C. (2012). Peningkatan pembelajaran di sekolah dasar dengan model kooperatif tipe make a match. Jurnal Pendidikan, 27(1), 61-68.

Lestari, K. B. (2012). Penerapan model pembelajaran tipe snow ball throwring untuk meningkatkan hasil belajar TIK siswa kelas VII SMP Negeri 4 Singaraja tahun ajaran 20112012. Jurnal Pendidikan Teknik Informatika, 1(4), 1-10.

Manik. A. (2012). Pengaruh penerapan model pembelajaran kooperatif tipe make a match menggunakan media handout terhadap hasil belajar kimia siswa pada pokok bahasan hidrokarbon di SMA. Skripsi Sarjana pada Program Studi Pendidikan Kimia. Universitas Negeri Medan.

Maula, M. \& Rustopo. (2012). Pengaruh model pembelajaran kooperatif tipe make a match terhadap hasil belajar matematika siswa kelas IV SD. Jurnal Penelitian, 2(2), 36-41.

Pandey, N. N. \& Kishore, K. (2003). Effect of cooperative learning on cognitive a chievement in science. Jurnal of Science and Mathematics Education in S.E Asia, 26(2), 52-60

Sudjana, N. \& Ibrahim, M. A. (2012). Penilaian dan penelitian pendidikan. Bandung: Sinar Baru Lagensindo.

Sugiyono. (2010). Statistika untuk penelitian. Bandung: Alfabeta.

Sulistyaningsih, F., Muliyani, S. \& Utomo, S. D. (2014). Penerapan model pembelajaran make a match berbantuan power point dilengkapi LKS untuk meningkatkan motivasi dan hasil belajar pada pokok bahasan isomer dan reaksi senyawa hidrokarbon kelas X SMA Batik 1 
Surakarta tahun pelajaran 2012/2013. Jurnal Pendidikan Kimia, 3(2), 82-92.

Sutarno, H. (2010). Penerapan pembelajaran cooperative integrated reading and composition (CIRC) berbasis komputer untuk meningkatkan hasil belajar siswa pada pembelajaran TIK. Jurnal Pendidikan Teknologi dan Informasi, 3(1), 1-9.
Suyono \& Haryanto, M. S. (2012). Belajar dan pembelajaran. Bandung: PT Remaja Rosdakarya.

Tran, V. D. (2014). The effect of cooperative learning on the academic achievment and knowledge retention. International Journal of Higher Education, 3(2), 131-140. 